\title{
Industry 4.0 : India's Defence Industry Needs Smart Manufacturing
}

\author{
Pawan Anand, Asha Nagendra
}

\begin{abstract}
The Fourth Industrial Revolution (I4.0) envisages fusion of technologies across the physical, digital and biological worlds, and is transforming production, management and governance into a Smart Manufacturing paradigm. It is based on exploitation of current and futuristic technologies such as Internet of Things, 3D Printing (Additive Manufacturing), $5 \mathrm{G}$ connectivity, cyber security, robotics and automation. More than any other industry, defence innovation and manufacturing demand high quality and precision products. This paper brings out the need and current status of India's defence manufacturing sector (state-controlled Defence Research and Development Organisation(DRDO), Ordnance Factories (OFs), Defence Public Sector Undertakings (DPSUs), and Private Industry including MSMEs) with regard to I4.0, and seeks to establish what needs to be done in adopting features of smart manufacturing, to make it globally competitive. Primary data obtained from a small but knowledgeable sample population, duly analysed with descriptive statistics; followed by secondary data sources, establish the influencing factors. Interpretive Structural Modelling helped formulate a framework for smart manufacturing in India's defence industry. The paper concludes with recommendations with regard to governmental, and industry stakeholders.
\end{abstract}

Key words: Artificial Intelligence India, India's Defence Industry, Industry 4.0, Smart Manufacturing

"New and emerging technologies like Artificial Intelligence and Robotics are perhaps the most important determinants of defensive and offensive capabilities for any defence force in the future. India, with its leadership in Information Technology domain, would strive to use this technology tilt to its advantage."

\section{Prime Minister Narendra Modi}

\section{INTRODUCTION}

The First Industrial Revolution in the mid-1780s was characterised by mechanisation, the Second in mid-1870s by electrification, and the Third in mid-1960s by automation. The Fourth Industrial Revolution, Industry 4.0 (I4.0), commenced about 2011 bringing together cyber and physical systems. It is creating within the factory, a networked industrial ecosystem allowing real-time data sharing and enabling human-machine and machine-machine interactions at an unprecedented speed and scale.

Smart Manufacturing (SM), synonymously used with I4.0, is a broad concept; not something that can be implemented in a production process directly. It is a

Revised Manuscript Received on September 10, 2019.

Pawan Anand, Faculty of Management Studies, Symbiosis Centre for Research \& Innovation, Symbiosis International (Deemed University), Pune, Maharashtra, India.

(Email: swapnapawan@ @ediffmail.com) combination of various technologies and solutions which are collectively implemented in a manufacturing ecosystem [1]. These "enabling" technologies and solutions help in optimizing the entire manufacturing process and increase overall profits.

\section{REVIEW OF LITERATURE}

The Digital Transformation Institute Report (2017) on global smart manufacturing trends outlines its benefits, the size of which is too large to ignore [2]:

- Smart factories could add $\$ 500$ billion to $\$ 1.5$ trillion in value to the global economy in five years

- Manufacturers predict overall efficiency to grow annually over the next five years at 7 times the rate of growth since 1990

- It is estimated that smart factories can nearly double operating profit and margin for an average automotive OEM manufacturer.

Table 1: Benefits of SM

\begin{tabular}{|l|c|c|}
\hline & Productivity & Quality \\
\hline Industrial Manufacturing & $20 \%$ & $20 \%$ \\
\hline Automotives & $19 \%$ & $19 \%$ \\
\hline Aerospace \& Defence & $17 \%$ & $15 \%$ \\
\hline
\end{tabular}

(Source: Capgemini Digital Transformation Institute, smart factory survey, February-March 2017, pp 1-4).

It further states 39\% manufacturers are struggling with the productivity figures in their smart factory initiatives, which it identifies and quantifies:

Challenges in formulating smart factory strategy lack of coordination among organisational units $32 \%$, leadership commitment $28 \%$, clear business case $28 \%$, ownership 23\%, vision $21 \%$.

- $\quad$ Challenges in implementing smart factory - lack of investment $29 \%$, maturity in lea shop floor automation processes $22 \%$, organisational inertia $21 \%$, identification and prioritisation of opportunities $21 \%$, roadmap $20 \%$.

- $72 \%$ of digital masters have leapt ahead of beginners $37 \%$. The difference lies in aggressive investment including training, and aggressive targets.

(Percentages are as per number of respondents who selected the option as a challenge)

In implementing smart factory strategies, manufacturers are classified in three categories: 
- Beginners - formulate a vision, establish foundation for strong leadership and governance, invest in digital initiatives aligned with vision, launch proofs -of concept and demonstrate early wins

- Digital Masters - Maintain focus on roadmap, sustain momentum by keeping people engaged, strive for digital culture as initiatives are advanced further.

- Conservatives - Ensure agility in governance models, prioritise and execute digital initiatives, scale up initiatives to organisational level.

KPMG-AIMA Report (2018) defines the technology levers or enablers for smart manufacturing, as under [3] :

Internet of Things (IoT). Establishes a connected value chain by networking machine to machines.

- Cloud Computing provides huge storage, networking and computational capabilities enabling interaction between technologies.

- $\quad$ Big Data Analytics. Creates capabilities to support intelligent and real-time decision making.

Additive Manufacturing or 3D Printing. Reduces lead time from product design to release, permitting customisation, and small batch production in a cost-effective manner.

- Augmented Reality. Uses mathematical modelling, Artificial Intelligence and virtual reality to enhance business generation.

- $\quad$ Robotics.Improves efficiency through automated manufacturing processes.

- Cyber security. Ensures secure communication protocols enabling data security.

- MachineLearning. Exploits industrial sensors and instruments to record and communicate data directly with software.

- Blockchain. This is a distributed infrastructure technology - it is a decentralized ledger that keeps a record of each transaction that occurs across a network which enables a decentralized exchange of trusted data $-\mathrm{a}$ 'shared record book".

A CII Report 2017 assesses the readiness of enterprises for I4.0 in six dimensions [4] :

- Strategy and organisation.

- Smart Factory. The production systems and logistics systems primarily organise themselves without human interventions, relying on cyber physical systems linked through IoT.

- Smart operations.

- Smart Products.

Physical components are equipped with sensors, RFID, communication interface etc. to collect data on their environment and their own status.

- Data-driven Services.

- $\quad$ Suitably skilled Employees

ILO Working Paper (2018) outlines the modest beginnings of emerging technologies in the Indian manufacturing ecosystem including DRDO and defence manufacturing. It laments the lack of basic infrastructure in terms of electricity, water, digital connectivity; preventing largescale exploitation of these technologies. It also identifies skill gaps in the labour force that restrict growth [5].

Deloitte Worldwide Survey (2018)of Aerospace \& Defence companies assessing state of I4.0 adoption across manufacturing industries concluded that $84 \%$ executives felt leveraging digital technologies was a keydifferentiator, only $25 \%$ were actually using these technologies to access, manage, analyse and leverage data to inform decision making in real time. The top challenge was identifying new business and delivery models in the course of their digital transformation. Key barriers were pace of technological change and lack of tech know how [6].

\section{A. Need for Smart Manufacturing Technologies Globally}

Countries have prioritised smart manufacturing in their future plans as a key enabler for growth; in Germany as "I4.0" in 2011, in USA as "Industrial Internet 2012" and in Japan as "Connected Factories" in 2015. India'schallenge as a low-cost manufacturer due to low labour costs is now under threat (Deloitte, 2018).

ASSOCHAM-Roland Berger Paper 2016 brings out the need to study the impact of I4.0 on India's environment, economy and society. Flexibility and mass customisation, direct client relationship, demand of skilled labour, asset rotation (low down time, reduced stocks), decentralisation of processes, fast product launch, supply chain agility and speed, optimisation of materials, reducing consumption, emission control, and how to make for safer workplace has been touched upon. Infrastructure for cloud computing which require massive data storing capabilities and computing power, need to be based within Indian borders. Access to private and public data needs to be enabled in usable and interoperable formats. There is lack of emphasis and investment on R\&D of relevant technologies. Skilling and training is slow, and educational curricula needs to reoriented. There is a need to relax trade barriers to encourage manufacturers to design and build labs and incentivise investment through start-ups / R\&D, encourage innovation and international engagement.I4.0 and Status if India's Manufacturing Ecosystem [7]

KPMG-AIMA Report 2018 opines India lags its global peers in I4.0 adoption. India is the 6th largest manufacturing country and GoI aims to raise manufacturing component of GDP from 17 percent in 2017 to $25 \%$ by 2022. Defence industry is expected to grow to USD 500 billion by 2025 [8].

Aulbur and Singh (2014) opine Automation and Robotics are still rare in Indian industry shop floors and virtually absent in the defence sector. Robot density per 10,000 employees in 2016 is a dismal 3 for India, while China stand at 68, US at 189, Germany at 309 and South Korea at 631 (global average being 74). The authors note that the World Economic Forum believes India's Network Readiness profile is hindered by its political, regulatory, business/innovation environment and lack of digital infrastructure, and places India below all other BRIC nations in it Network Readiness Index in 2013 and 2014.India has a

Published By

Blue Eyes Intelligence Engineering

\& Sciences Publication 
vocational training capacity of just 44 lakhs for an over 50 crore workforces, standing at $0.8 \%$ against $6.7 \%$ in the US and $11.5 \%$ in China. India's formally skilled workforce stands at $4.7 \%$ vis-à-vis $24 \%$ in China, $68 \%$ in UK, $75 \%$ in Germany and $96 \%$ in South Korea [9].

KPMG-AIMA Report (2018) notesthe automotive sector also employs additive manufacturing/3D printing in their $\mathrm{R} \& \mathrm{D}$ centre to develop prototypes and reduce time to market. Collaborative robots (Co-Bots) are enhancing productivity (risen from 507 to 804 vehicles per person per year). Textile industry has reduced wastage and organised production flows with "Intelligent plant framework" in a Mumbai based company, and "connected machines" at a Bengaluru based packaging company has assisted put predictive maintenance in place The first in India was a Brilliant Factory created in Pune by an American conglomerate in 2015, with an investment of Rs 1000 crore. India's strength in two critical enabling technologies, IoT and Big Data, should give impetus to creation of smart factories. India's share should rightfully be $20 \%$ of the global IOT market $32 \%$ of global Big Data analytics.On the positive side, the services sector has seen significant uptake in AI, particularly the IT sector [10].A number of private sector companies have developed and adopted software for intelligent manufacturing. GE has established a Brilliant Factory that brings together $3 \mathrm{D}$ printing, IoT, big data analytics, cloud computing and AI to support decision making with real time visibility and operational intelligence, to facilitate production of jet engines, locomotive technology, wind turbines etc. Under Make in India, GoI has invited GE to expand its production to include shipbuilding and defence manufacturing. India's Defence Manufacturing Ecosystem. It is comprised of 52 defence laboratories and establishments of the DRDO, nine DPSUs, 39 OFs and a growing private sector participation base including over 1200 MSMEs. Self-reliance is a key goal of the government and ToT (Transfer of Technology) arrangements, often ushered in through the offsets policy route involved licensed production; and increasingly Joint Venture (JVs) with foreign OEMS. Government policies favouring Foreign Direct Investment (FDI) up to $49 \%$ stake by foreign OEMs through the automatic route, and up to $100 \%$ on case to case basis cleared by Government have made co-development and co-production more lucrative for all concerned stakeholders [11](Behera 2013).

Geethanjali, Hickok and Sinha (2016)recommend that a collaborative approach with all stakeholders is essential, viz.

* Practitioners. A large number of private companies in defence manufacturing may have taken to incorporating smart manufacturing based on some if not all aspects of the contributing technologies. However, DPSUs and OFs still employ archaic processes, despite raising the bar with licensed production as in BDL,BEML and BEL; but other OFs manufacturing rifles, clothing, shoes etc for the armed forces remain in the technologies of the 1950-60s.

* R\&D Bodies. These include academic institutions, industry bodies and DRDO.

* Government. In 2015, the IoT Policy was launched aimed to propel skill development, technological upgrades and building IoT products. In 2017 GoI rolled out the National Manufacturing Policy consolidating the Make in
India Initiative and meeting the requirement of upgrading skills for redeployment. The National Program om AI has been announced with NITI Aayog creating a roadmap for new AI applications, in 2019. A Centre for Excellence (COE) on IT for I4.0 is being set up to act as a knowledge centre for entrepreneurs and start-ups propagating applications for I4.0, and a Cyber-Physical System mission was announced in Union Budget 2018-19 to support establishment of the COE for training in robotics, AI, digital manufacturing etc. In addition, a National Policy for Advanced Manufacturing is being worked out to enhance global competitiveness. NITI Aayog's portal has been launched to share practice data sets, and The AI Task Force is drafting effective policy. Digital India, Make in India and Skill India Initiatives have begun the process of adoption of I4.0 into manufacturing and re-skilling workforces. The Commerce Ministry has set up its own Task Force on AI.

* Funders/Investors. Firms such as Kalaari Capital, Sequoia et al and Reliance, Tata Group etc are funding a large number of start-ups.

* Developers. Some 83 companies have developed AI enabled products, 62 being purely Indian entities [12].

DRDO. The DRDO employs some 7,255 scientists and 13,370 technicians and accounts for less than $7 \%$ of India's defence budget, tasked with fundamental and application research to develop technologies indigenously. Its financial management is done through government defined procedures called the procurement manual, which is often too bureaucratic to allow the necessary freedom for basic research and state of the art strategic projects.

DPSUs. India's nine DPSUs are public sector corporate entities with relative financial and operational freedom manufacturing high end technology products (such as aerospace, electronics, warships and missiles) at Hindustan Aeronautics Ltd, Bharat Electronics Ltd, Bharat Earth Movers Ltd, Mazagaon Docks Ltd, Goa Shipyard ltd, Garden Reach Shipbuilders and Engineers Ltd, Bharat Dynamics Ltd, Hindustan Shipyard Ltd and MIDHANI (for metals, materials and alloys) [13]. He felt that FDI policy needs to be increased from $26 \%$ to at least $74 \%$ to attract the best technologies and even $100 \%$ for niche technologies. Optimisation of production lines and supply chains would bring in much needed cost efficiencies. DPSUs are under control of MOD and are the largest production agencies for defence items on a nomination basis, thus beyond competitive market forces. Behera (2016) states they are plagued with low value addition and highly dependent on external sourcing. Prahalda (2016) states that the defence industry is focussed on profits, risk-free business, large volumes, repeat orders and contracts for annual maintenance. The DPSUs tend to avoid open competition with private industry and even demand government protection despite huge infrastructure. Their inability to adopt dual use technology products hampers agility in product inventory, orders management, export and quality [14]. 
OFs. OFs are in five operating divisions based on the main products/technologies employed, viz, Ammunition \& Explosives (A\&E) - 10 Factories; Weapons, Vehicles and Equipment (WV\&E)-10 Factories; Materials and Components (M\&C)-9 Factories; Armoured Vehicles (AV)_-5 Factories; Ordnance Equipment Group of Factories (OEF) - 5 Factories. Prasad (2016) felt the OFs have a large asset bae in terms of buildings, modern plant and machinery and a skilled work force of around 100,000 employees. They are trying to progress from manual to automated processes to produce armoured vehicles like tanks and infantry combat vehicles, mine-protected vehicles, military transport, weapons, naval ships and helicopters, combat aircraft till clothing and shoes for the armed forces. She opines they lack sustained growth, fall short in meeting targets by a large margin, have low productivity, and are cost inefficient and plagued with quality issues, mainly due to bureaucratic procedures and unionisation of labour. She feels self-reliance in defence manufacturing which can be achieved through "formation of consortia, joint venture and public private partnerships". Public-Private Partnerships (PPP) support in house R\&D to bring in cutting edge technologies. Smart manufacturing technologies will get ushered in through this route, and can then be used for dual use products as well [15].

The manufacturing ecosystem comprising of the OFs and DPSUs draws on technology from the DRDO and foreign OEMs. Their capability to produce quality products is dependent on the capacity of these manufacturing units to absorb technology. Dual use technologies will enable defence manufacturers remain economically viable. OFs need to be agile, requiring highly progressive and digitally aware managements, responsive to fast paced changes in smart manufacturing methodologies and strategies [16].

The role of Management and Leadership in improving productivity, quality, reliability and dependability of defence products has been emphasised by Ghosh [17]. He felt shortened technology cycles will impose the need for frequent upgrades to keep pace with adversaries' weapon systems.

Sniderman, Mahto and Cotteleer (2017) opine that despite India's advantage in the IT sector, shortage of talent capable of integrating IT with OT (Operations Technology), continue to dog the manufacturing sector. In a bid to protect proprietary rights and retaining margins, OEMs create incompatible hardware or software which makes seamless integration a major exercise and tends to roadblock upgradation efforts. Lack of standardisation and interoperability of systems is another major challenge. Laws need to be fine-tuned for resolving issues of data control and ownership as suppliers and manufacturers become increasingly intertwined [18].

\section{B. Need for SM in India's Defence Industry.}

Poonian (2019)opines that Digital transformation in manufacturing units of the DIB is the need of the hour. Its benefits are enumerated below:

Usher in upscaled state of art technologies matching with military qualitative requirements. This will also help improve technology absorption from foreign vendors and JV partners. This will also enable achieve better terms and conditions of contracts involving transfer of technology (ToT).

$>$ Reduce cost of periodic upgrades in models of introduced military weapons and equipment

Meet the requirements of high reliability and dependability in defence related products ensuring quality combined with ruggedization.

Meet the requirement for constant innovation to maintain cutting edge in technology over adversaries.

$>$ Exploit opportunities for commercialisation and export to strategically aligned countries

Provides agility in manufacturing by enabling swapping of suppliers when necessitated by geopolitical considerations, maintain control over IPR and ensure timely deliveries to defence forces.

Reduces need for holding reserve stocks of equipment and spares, by providing the means to create surge capacities (speeding up production) in short timeframes [19].

\section{RESEARCH GAPS}

Sufficient literature is available on the need to adopt I4.0 technologies for smart manufacturing globally, and its implementation in various industrial sectors in India. However, smart manufacturing seems to be eluding its defence industrial base comprising of the DRDO, DPSUs, OFs and private defence enterprises including MSMEs. The undermentioned research gaps in the smart manufacturing paradigm in India's defence manufacturing sector were :

- What are the challenges to adopt Smart Manufacturing in India's defence industry?

- What issues influence the adoption of I4.0?

- What needs to done to adopt the Smart Manufacturing paradigm in an early timeframe?

\section{RESEARCH OBJECTIVES}

In the case of India's defence manufacturing ecosystem, this paper seeks to

- Establish the requirement for adopting I4.0 technology

- Identify the factors influencing Smart Manufacturing

- $\quad$ Formulate a framework for adopting SM in India's defence industrial base.

\section{RESEARCH METHODLOGY}

Primary data. This was obtained by conducting a survey with the help of a structured questionnaire sent to professionals in the field of defence procurement and manufacturing viz officials of the DRDO, Ministry of Defence (Army), defence entrepreneurs, a strategic think tank, infrastructure experts etc.

Secondary data. Secondary data was obtained from existing sources of the literature review. 
Interpretive Structural Modelling (ISM). Factors influencing the defence smart manufacturing paradigm were identified from the literature review and survey. ISM then helped arrive at a framework to be adopted, in an unbiased manner.

\section{SURVEY AND ANALYSIS OF DATA}

A structured questionnaire was administered to 20 knowledgably individuals across relevant departments concerned with defence manufacturing and smart manufacturing technologies. 16 individuals responded.

* $\quad 93 \%$ respondents agreed (A) or strongly agreed (SA) that India's defence manufacturing scenario was plagued with poor quality and that smart manufacturing would contribute in improving product quality.

* $\quad 94 \%$ A/SA that I4.0 technologies would improve productivity in defence manufacturing both in public and private sector. There was complete consensus that DPSUs and OFs would greatly benefit by retro fitment of smart manufacturing technologies, and to help them switch to dual use technology products.

* Only $12.5 \%$ respondents were neutral to the idea that the largely unskilled work force in the defence manufacturing sector would resist transformation, with 87.5 $\%$ respondents $\mathrm{A} / \mathrm{SA}$ that policies will need to be made to re-skill them and provide protection/compensation for loss of jobs. $81.5 \% \mathrm{~A} / \mathrm{SA}$ that those workers who are unable to re-skill need to be laid off with a golden handshake package. There was near complete consensus that smart manufacturing would contribute to product improvement and in-house R\&D.

* About $40 \%$ respondents expressed doubt in the capability of India's IT industry to provide watertight data security and uninterruptable internet connectivity. $80 \%$ respondents were of the view that government needs to subsidise and incentivise defence industrial players to invest in smart manufacturing. $44 \%$ disagreed that the work force was incapable of re-skilling in defence manufacturing work space, while about $19 \%$ remained neutral. All respondent A/ that though private manufacturers would convert to smart factories, the DPSUs and OFs will need to be forced into it in the next decade or so.

\section{INTERPRETATIVE STRUCTURAL MODELLING}

Influencing Factors emerged from the literature review and analysis of survey.
Table 3: Influencing Factors in adoption of SM in India's Defence Industry

\begin{tabular}{|c|c|c|c|}
\hline FNo & Factor & Code & References \\
\hline 1 & $\begin{array}{l}\text { Management } \\
\text { Strategy and } \\
\text { Leadership }\end{array}$ & MSL & $\begin{array}{l}\text { KPMG-AIMA } \\
\text { Report 2018, } \\
\text { Ghosh 2016, } \\
\text { Behera 2013 }\end{array}$ \\
\hline 2 & $\begin{array}{l}\text { Government } \\
\text { Policies/ } \\
\text { Incentives }\end{array}$ & GPI & $\begin{array}{l}\text { Behera 2013, } \\
\text { Ghosh 2016, } \\
\text { Poonian 2019, } \\
\text { FICCI } 2016\end{array}$ \\
\hline 3 & $\begin{array}{l}\text { Labour } \\
\text { laws/unions }\end{array}$ & LAB & $\begin{array}{l}\text { Ghosh 2016, } \\
\text { Behera 2013, } \\
\text { Deloitte 2018, } \\
\text { FICCI 2016 }\end{array}$ \\
\hline 4 & $\begin{array}{l}\text { Workforce Re- } \\
\text { skilling } \\
\text { capabilities }\end{array}$ & ReSk & $\begin{array}{l}\text { Ghosh 2016, } \\
\text { Behera 2013, } \\
\text { ILO2018, Deloitte } \\
2018 \text {, }\end{array}$ \\
\hline 5 & $\begin{array}{l}\text { Optimisation of } \\
\text { production \& } \\
\text { supply chain }\end{array}$ & Opti & $\begin{array}{l}\text { Digital Institute } \\
\text { 2019, Poonian } \\
\text { 2019, Prahalada } \\
2016, \text { Prasad } 2016\end{array}$ \\
\hline 6 & $\begin{array}{l}\text { Improved } \\
\text { quality } / \mathrm{Upg}_{\text {prades }}\end{array}$ & $\mathrm{Q} / \mathrm{U}$ & $\begin{array}{l}\text { Behera 2016, } \\
\text { Prasad 2016, } \\
\text { Poonian 2019 }\end{array}$ \\
\hline 7 & $\begin{array}{l}\text { Capability for } \\
\text { technical } \\
\text { absorption }\end{array}$ & TA & $\begin{array}{l}\text { Geethanjali } 2016 \text {, } \\
\text { Deloitte } 2018 \text {, } \\
\text { Aulbur\& Singh } \\
2014\end{array}$ \\
\hline 8 & $\begin{array}{l}\text { Availability of } \\
\text { stable } \\
\text { infrastructure }\end{array}$ & Infra & $\begin{array}{l}\text { ILO 2018, } \\
\text { Deloitte } 2018\end{array}$ \\
\hline 9 & $\begin{array}{l}\text { Dualuse } \\
\text { technical } \\
\text { products }\end{array}$ & DUTP & $\begin{array}{l}\text { Poonian 2019, } \\
\text { Ghosh 2016, } \\
\text { Behera 2016 }\end{array}$ \\
\hline
\end{tabular}

ISM was used to develop a structural model amoung these influencing factors. It assisted in establishing their responsiveness and determining the relationship between dependent and driving factors.

Steps

$>$ Identification of factors from the literature survey.

Establishing the contextual relationship between pairs of factors in the form of a Structural Self-Interaction Matrix SSIM (Appendix Table 5)

$>$ SSIM was then converted into a binary matrix called the initial reachability matrix substituting (Appendix Table 6)

$>\quad$ This led to the Final Reachability Matrix, wherein the driving power DP and dependence (Dep) is obtained (Table 6)

$>$ Level partitioning was then carried out find the level for each factor. This entailed finding the reachability set and antecedent set for each factor. The intersection is derived for each factor. The factor for which intersection set matched reachability set, was removed from the next iteration and assigned level I. Thereafter, the process was repeated till all levels were determined. (Appendix Tables 7 to 13 )

Factors were then placed in the Modelling Matrix classifying each as autonomous, dependent, linkage and drivers, based on their DP and Dep. (Appendix Table 14)

The interaction of each with the other was drawn out as a line arrows, to obtain the Directed Graph or Digraph. (Fig. 1) 
$>\quad$ Finally, each factor was placed in the digraph and the arrows showing transitivity taken off. This established the Interpretive Model Framework as shown in the following page. (Figure 2)

Table 5 : Structural Self Interaction matrix of Factors

\begin{tabular}{|c|c|c|c|c|c|c|c|c|c|c|}
\hline $\mathrm{S}$ & Critical & 1 & 2 & 3 & 4 & 5 & 6 & 7 & 8 & 9 \\
\hline No & Factors & MSL & GPI & Lab & ReSk & Optim & $\mathrm{Q} / \mathrm{U}$ & TA & Infra & $\begin{array}{l}\text { DuT } \\
\mathrm{p}\end{array}$ \\
\hline 1 & MSL & & $\mathrm{A}$ & $\mathrm{A}$ & $\mathrm{V}$ & V & $\mathrm{V}$ & $\mathrm{V}$ & $\mathrm{V}$ & V \\
\hline 2 & GPI & & & $\mathrm{A}$ & $\mathrm{V}$ & $\mathrm{V}$ & $\mathrm{V}$ & $\mathrm{V}$ & $\mathrm{V}$ & $\mathrm{V}$ \\
\hline 3 & Lab & & & & $\mathrm{V}$ & $\mathrm{V}$ & $\mathrm{V}$ & $\mathrm{O}$ & $\mathrm{O}$ & $\mathrm{O}$ \\
\hline 4 & ReSk & & & & & $\mathrm{V}$ & $\mathrm{V}$ & $\mathrm{V}$ & $\mathrm{X}$ & $\mathrm{X}$ \\
\hline 5 & Optim & & & & & & $\mathrm{O}$ & $\mathrm{O}$ & $\mathrm{X}$ & $\mathrm{X}$ \\
\hline 6 & $\mathrm{Q} / \mathrm{U}$ & & & & & & & $\mathrm{A}$ & $\mathrm{A}$ & $\mathrm{O}$ \\
\hline 7 & TA & & & & & & & & $\mathrm{X}$ & $\mathrm{X}$ \\
\hline 8 & Infra & & & & & & & & & $\mathrm{V}$ \\
\hline 9 & DuTp & & & & & & & & & \\
\hline
\end{tabular}

Table 6 : Final Reachablity Matrix of Factors

\begin{tabular}{|c|l|c|c|c|c|c|c|c|c|c|c|}
\hline $\begin{array}{c}\text { S. } \\
\text { No }\end{array}$ & $\underline{\text { Factors }}$ & 1 & 2 & 3 & 4 & 5 & 6 & 7 & 8 & 9 & \\
\cline { 3 - 13 } & MSL & GPI & Lab & ReSk & Optim & Q/U & TA & $\begin{array}{l}\text { Infr } \\
\text { a }\end{array}$ & $\begin{array}{l}\text { DuT } \\
\text { p }\end{array}$ & DP \\
\hline 1 & $\begin{array}{l}\text { MS } \\
\text { L }\end{array}$ & 1 & 0 & 0 & 1 & 1 & 1 & 1 & 1 & 1 & 7 \\
\hline 2 & GPI & 1 & 1 & 0 & 1 & 1 & 1 & 1 & 1 & 1 & 8 \\
\hline 3 & Lab & 1 & 1 & 1 & 1 & 1 & 1 & 0 & 0 & 0 & 6 \\
\hline 4 & $\begin{array}{l}\text { ReS } \\
\text { k }\end{array}$ & 0 & 0 & 0 & 1 & 1 & 1 & 1 & 1 & 1 & 6 \\
\hline 5 & $\begin{array}{l}\text { Opti } \\
\mathrm{m}\end{array}$ & 0 & 0 & 0 & 0 & 1 & 0 & 0 & 1 & 1 & 3 \\
\hline 6 & Q/U & 0 & 0 & 0 & 0 & 0 & 1 & 0 & 0 & 0 & 1 \\
\hline 7 & TA & 0 & 0 & 0 & 0 & 0 & 1 & 1 & 1 & 1 & 4 \\
\hline 8 & Infra & 0 & 0 & 0 & 1 & 1 & 1 & 1 & 1 & 1 & 6 \\
\hline 9 & $\begin{array}{l}\text { DuT } \\
\mathrm{p}\end{array}$ & 0 & 0 & 0 & 1 & 1 & 0 & 1 & 0 & 1 & 4 \\
\hline 10 & $\begin{array}{l}\text { Dep } \\
.\end{array}$ & 3 & 2 & 1 & 6 & 7 & 7 & 6 & 6 & 7 & 45 \\
\hline
\end{tabular}

Table 7 : Level Partitioning through Seven Iterations

\begin{tabular}{|l|l|l|l|l|}
\hline \multicolumn{1}{|c|}{ Factor } & $\begin{array}{c}\text { Reachability } \\
\text { Set }\end{array}$ & $\begin{array}{c}\text { Antecedent } \\
\text { Set }\end{array}$ & $\begin{array}{l}\text { Intersection } \\
\text { Set }\end{array}$ & Level \\
\hline 1. MSL & 1 & $1,2,3$ & 1 & V \\
\hline 2. GPI & 2 & 2,3 & 2 & VI \\
\hline 3. Lab & 3 & 3 & 3 & VII \\
\hline 4. ReSk & 4 & $1,2,3,4$ & 4 & IV \\
\hline 5. Optim & $5,8,9$ & $\begin{array}{l}1,2,3,4, \\
5,8,9\end{array}$ & $5,8,9$ & II \\
\hline 6. Q/U & 6 & $\begin{array}{l}1,2,3,4, \\
6,7,8\end{array}$ & 6 & I \\
\hline 7. TA & $7,8,9$ & $\begin{array}{l}1,2,4,7, \\
8,9\end{array}$ & $7,8,9$ & II \\
\hline 8. Infra & 4,8 & $1,2,3,4$ & 4,8 & III \\
\hline 9.DUTP & $4,5,7,9$ & $\begin{array}{l}1,2,4,5, \\
7,8,9\end{array}$ & $4,5,7,9$ & II \\
\hline
\end{tabular}

\section{Autonomous Dependent}

Dependence
Fig 1 : Diagraph of factors

Table 14: Modelling of Factors influencing SM in India's Defence Industry

\begin{tabular}{|c|c|c|c|c|}
\hline & & & & \\
\hline & $\begin{array}{c}\text { Infra, } \\
\text { ReSk }\end{array}$ & & & \\
\hline & & & & \\
\hline & TA & DUTP & & \\
\hline & & Optim & & \\
\hline & & & & \\
\hline & & Q/U & & \\
\hline 5 & 6 & 7 & 8 & 9 \\
\hline
\end{tabular}


Fig 2: ISM based model for critical factors

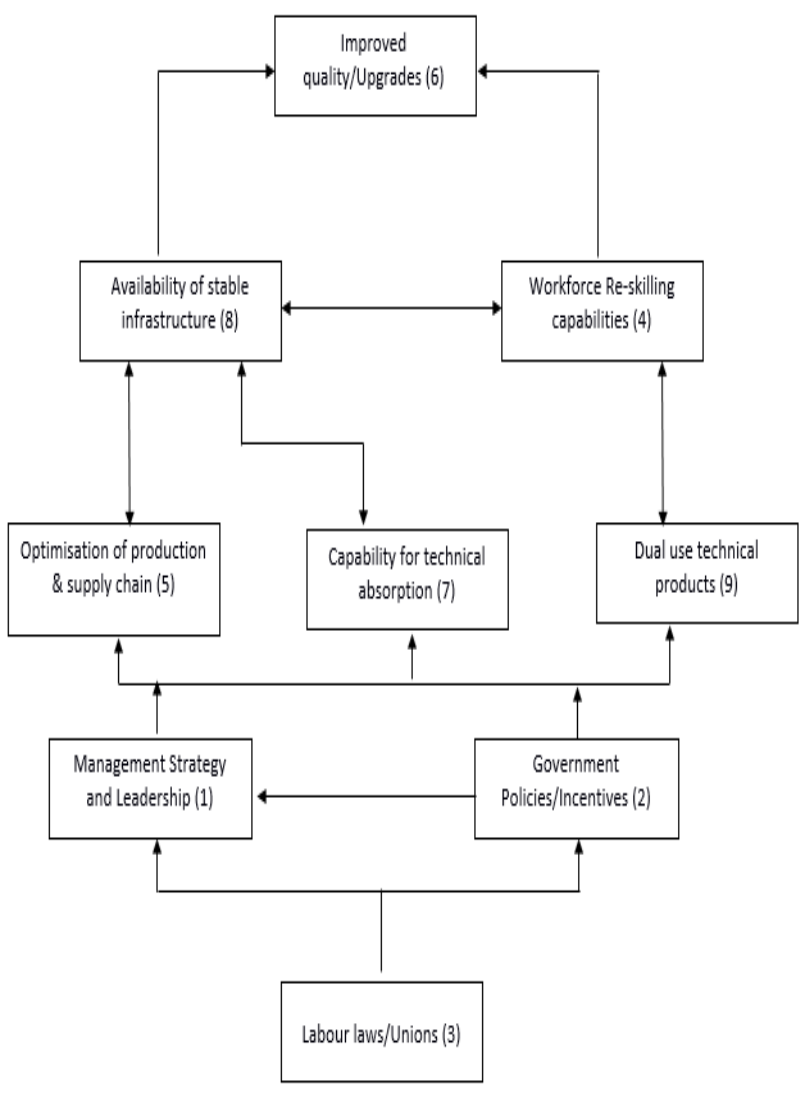

\section{FINDINGS \& RESULTS}

The Literature survey helped identify the under mentioned challenges to adoption of SM to India's defence manufacturing ecosystem:

- High cost of physical and digital/technical infrastructure.

- $\quad$ Cyber security related risks.

- Data privacy regulations (need to be strengthened).

- $\quad$ Leadership skill gap - knowledge and agility

- Work force skill gap - expertise in I4.0 technologies.

- $\quad$ Training including vocational training

- Type of process and work organization.

- Standards and interoperability in the interconnected ecosystem

- Data control and ownership as suppliers and manufacturers become increasingly intertwined

- $\quad$ Lack of research and specialist staff

- Suppliers of mechatronic system and machineries are limited

- Weak network infrastructure

- $\quad$ Lack of effective plant layout

Primary data duly analysed and ISM lead onto the following findings:

Smart Manufacturing (SM) would immensely contribute to improving the quality, productivity, and in-house R\&D of domestic defence manufacturers. product improvement leading to product improvement.

SM technologies can be retro-fitted to existing domestic plants and would benefit them in developing the agility to switch to dual use products, thereby improving productivity and enhancing profitability.

$>$ Industrial workforce in the sector will need to be retrained to be able to work in a smart factory environment. Those unable to adapt will need to be re-skilled in other tasks if their services are to be retained, or suitable compensation given to assist them in seeking other avenues of employment/retirement.

$>$ SM demands data/cyber security and suitable infrastructure which will need to be ensured by government agencies and suitable policy initiatives. Defence Manufacturers will need to offered incentives to adopt SM technologies in view of their high capital costs and the risks involved in defence contracts. Top driven efforts by the management and leadership in term of policy, planning and implementation will be essential. SM will make DPSUs and OFS more competitive so as to be able to compete with domestic private sector defence manufacturers and foreign OEMs.

Government will need to revise its industrial and manufacturing policies to ensure SM is not only forced upon manufacturers but also incentivised in terms of subsidies and financing schemes.

Labour laws and unionisation is one of the primary factors which influences not only governmental policies but also management strategies and leadership patterns to adoption SM in the defence manufacturing ecosystem.

$>$ Drivers with low dependence viz Management Strategy and Leadership will pave the way for adoption of SM. These need to be suitably educated and convinced to implement SM strategies and commit funds. These would then influence the quality of product, the ability to absorb technologies, and improve efficiencies in the supply chain. While re-skilling the work force for SM is essential, it may not be as difficult as it may seem initially. On the other hand, current strengths like existing infrastructure with OFs, DPSUs and DRDO, India's advantage in industrial IoT and IT skills, and the ability to adopt AI needs to be exploited fully.

It is evident that in the classification of I4.0 industry levels vide the Digital Transformation Institute Report 2017 referred to at page 3 above, India's private defence industry is a "Beginner"; while DPSUs, DRDO and OFs are in the "Conservative" category. (Page 3 refers).

\section{RECOMMENDATIONS/CONCLUSIONS}

India's advantage of 3Ds - democracy, demography and demand - a growing, technically savvy labour and low-cost manufacturing, need to be built upon. Government support to create a suitable ecosystem and show readiness to adopt and invest, accelerate innovation with PPP and support industrial bodies will now be critical. It must help industry to develop roadmaps, tailored strategies and implementation methodologies with measurable outcomes.

Ministry of Industries and Department of Defence Production need to set up a dedicated wing for adoption of I4.0, establish test labs country wide, to advance I4.0 which

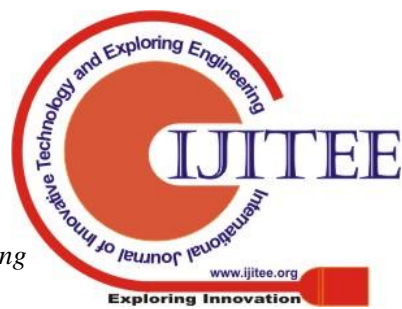


would keep pace with global standards. Incentives for MSMEs to adopt smart manufacturing along with provision of low-cost capital will need to be addressed. FDI in the field will need to be encouraged and ease of doing business improved.

Defence industry will need to redefine managerial role, invest in skilling its leadership, provide skilling opportunities to employees, providing cross functional exposures. They will need to invest in in-house R\&D. Soft skills like critical thinking, creativity, emotional intelligence, judgement and cognitive flexibility will be the need of leadership 4.0. Digital knowledge, cyber security and data protection will need to be understood deeply by managements. The work force will need applied vocational training, and training institutes will need to be created / upgraded to up-skill existing personnel.

The social impact of job losses will have to be taken into account. Labour unions would oppose change, highlighting the need to emphasise re-skilling. Government will need to devise means to compensate workers being laid off. The South Korean model of imposing Robot Tax on companies laying off workers due to automation could be considered, and the same be used to compensate laid off workers or provide incentives to companies for re-training or re- skilling. The concept of providing Universal Basic Income will need to be explored.

The education system will need re-thought and skill map upgraded. Government will need to create jobs, involve private sector in PPP to conduct training, forcefully implement Skill India initiatives and put in place policies for industry to utilise only qualified artisans. It will need to promote original research, build policies for curriculums to be modified to industry requirements, and bolster vocational training infrastructure in partnership with industry.

Academia to will need to enhance curriculum, and modernise learning infrastructure, align curricula to specific defence industry requirements, focus on practical knowledge gain, create massive open online courses and collaborate with defence industry to set up smart factories.

Future champions in industry will only emerge when competitiveness is driven by focussed technology development, R\&D and global market access, continuity of management and supplier management, and optimisation. The IoT rides telecom infrastructure, for which the Digital India fibre optic network should address the digital infrastructure gap and provide reliable support in telecommunication and power.

Table 4: Application of SM Technologies

Aerospace and Defense 4.0 has a multitude of current and emerging applications

\begin{tabular}{|c|c|c|}
\hline Technology & Current applications & Emerging applications \\
\hline $\begin{array}{l}\text { Additive } \\
\text { manufacturing }\end{array}$ & $\begin{array}{l}\text { Prototyping, tooling, and functional end-use } \\
\text { parts manufacturing }\end{array}$ & $\begin{array}{l}\text { Combining new types of novel materials to } \\
\text { improve aerospace parts and accessories }\end{array}$ \\
\hline $\begin{array}{l}\text { Advanced } \\
\text { analytics }\end{array}$ & $\begin{array}{l}\text { Monitoring real-time aircraft health: } \\
\text { identifying system/component failures in } \\
\text { advance; making intelligent scheduling and } \\
\text { forecasting models }\end{array}$ & $\begin{array}{l}\text { Developing large-scale digitization of plane } \\
\text { maintenance data and schedules; creating } \\
\text { synergies across business and functional } \\
\text { areas by enabling the "connected plane" }\end{array}$ \\
\hline $\begin{array}{l}\text { Advanced } \\
\text { robotics and } \\
\text { cognitive } \\
\text { automation }\end{array}$ & $\begin{array}{l}\text { Using robotics in aircraft manufacturing for } \\
\text { more efficient production, with fewer errors } \\
\text { and quality issues }\end{array}$ & $\begin{array}{l}\text { Simplifying simulations of aircraft, weapons, } \\
\text { and satellite performance, avoiding time- } \\
\text { consuming analysis and tests of algorithms, } \\
\text { software, and hardware }\end{array}$ \\
\hline $\begin{array}{l}\text { Artificial } \\
\text { intelligence }\end{array}$ & $\begin{array}{l}\text { Applying Al to robotics, automatic } \\
\text { programming of tasks and processes in } \\
\text { industrial settings, and enabling predictive } \\
\text { maintenance }\end{array}$ & $\begin{array}{l}\text { Leveraging Al and computer vision } \\
\text { technologies to augment advanced safety } \\
\text { features in aircraft: incorporating advanced } \\
\text { Al into drones; and replacing human copilots } \\
\text { in new, autonomous aircraft }\end{array}$ \\
\hline Blockchain & $\begin{array}{l}\text { Enabling greater transparency of information } \\
\text { between different parties; improving just-in- } \\
\text { time logistics; reducing erroneous orders: } \\
\text { improving inventory turnover }\end{array}$ & $\begin{array}{l}\text { Improving tracking in supply chains and } \\
\text { procurement using a shared database with } \\
\text { suppliers and partners: improving validation } \\
\text { of supplier performance and reputation; and } \\
\text { time-stamping records to reduce fraud and } \\
\text { improve supply chain security }\end{array}$ \\
\hline $\begin{array}{l}\text { Digital reality } \\
\text { (AR/VR/mixed } \\
\text { reality) }\end{array}$ & $\begin{array}{l}\text { Replacing assembly manuals with smart- } \\
\text { glasses displays, which substantially reduces } \\
\text { wiring production time }\end{array}$ & $\begin{array}{l}\text { Using VR to optimize and design factories, } \\
\text { and simulate an entire factory or warehouse } \\
\text { to train workers to use equipment more } \\
\text { safely and efficiently }\end{array}$ \\
\hline $\begin{array}{l}\text { Internet of } \\
\text { Things }\end{array}$ & $\begin{array}{l}\text { Monitoring aircraft engine health and } \\
\text { optimizing engine performance based on } \\
\text { data collected from sensors }\end{array}$ & $\begin{array}{l}\text { Managing material costs and demand } \\
\text { fluctuations by analyzing big data, enabling } \\
\text { integrated smart connected assets and } \\
\text { operations, and, eventually, an autonomous } \\
\text { production environment }\end{array}$ \\
\hline
\end{tabular}

Source: Michelle Drew Rodriguez et al., Exponential technologies in manufacturing, Deloitte, 2018 
Aulbur and Singh (2014) had stressed the need for JVs and PPP to accelerate innovation in a sustainable manner. Fundamental research and academia need capital intensive infrastructure to be supported by government. Major defence industrial houses can focus on product specific R\&D while off shoots can be shared with Tier 2 and 3 MSMEs.

In defence manufacturing PPP is a complex Government and Private industry partnership which often involves foreign players, labs and logistical infrastructure. The laws and regulations pertaining to each of these stakeholders need to be factored in at an early stage as brought out by Poonian (2019). Many times, volatile geo political issues influence these partnerships. They therefore need to take in the longterm perspectives of all partners which include national security, alliances, IPR protection coupled with the overriding motive of profit.

Government and manufacturing managers need to together identify priorities in defence manufacturing requirements, build partnerships, define apportionment/distribution of responsibilities in $R \& D$ and smart products, and establish costing norms to reassure private manufactures of returns on their investment in smart manufacturing tools and employee training.

\section{REFERENCES}

1. P Raushan , 2018, https://blog.marketresearch.com/thetop-7-things-to-know-about-smart-manufacturing, Para 3.

2. Smart Factories: How can manufacturers realize the potential of digital industrial revolution", The Digital Consulting, $\quad$ https://www.capgemini.com/wpcontent/uploads/2017/07/smart_factories-

how_can_manufacturers_-

realize_the_potential_of_digital_industrial_revolution.pd f. Accessed on 15 May 2019)

3. Industry 4.0 : India Inc Gearing Up for Change, KPMGAIMA Report 2018, pp 15. http://resources.aima.in /presentations/AIMA-KPMG-industry-4-0-report.pdf

4. Swarnima Chouhan, Priyanka Mehra, Ankita Dasot, "India's readiness for industry 4.0: A focus on automotive sector" CII-Grant Thornton 2017, https://www.grantthornton.in /globalassets/1.-memberfirms/india/assets/pdfs

/indias_readiness_for_industry_4_a_focus_on_automotiv e_sector.pdf

5. Emerging technologies and the future of work in India", ILO Asia-Pacific Working Paper Series, June 2018, pp 67, ISSN: 2227-4391 (print); 2227-4405 (web pdf)

6. Robin Lineberger, Aijaz Hussain, Tim Hanley et al "Aerospace \&Defense 4.0:Capturing the value of Industry 4.0 technologies" pp20-21. Deloitte Insights, https://www2.deloitte.com /insights/us/en/focus/industry4-0/aerospace-defense-companies-digital-

transformation.html

7. 'Industry 4.0 : Smart Manufacturing; Enabler for enhanced competiveness of Indian Manufacturing Sector October 2016 ASSOOCHAM and Roland Berger, http://publication.assocham.tv/data/product-file/40\%20$\% 20$ Background $\% 20$ paper $\% 20$

8. Industry 4.0 : India Inc Gearing Up for Change, KPMGAIMA Report 2018, pp 4-6, http://resources.aima.in/presentations/AIMA-KPMGindustry-4-0-report.pdf

9. Aulbur and Singh H V, The Next Gen Manufacturing: Industry 4.0" CII - Roland Berger theme paper (2014), Transformation Institute Report, 2017 Capemini

https://www.gita.org.in/Attachments/Reports/CII\%20Rol and $\% 20$ Berger $\% 20$ Industry $\% 2040 . p d f$

10. Industry 4.0 : India Inc Gearing Up for Change, KPMGAIMA Report 2018, pp 9-10. http://resources.aima.in /presentations/AIMA-KPMG-industry-4-0-report.pdf

11. Behera LK (2013), "Indian Defence Industry: Issues Of Self-Reliance", IDSA Monograph Series No 21, pp 10, July 2013, https://idsa.in/system/files/monograph21.pdf,.

12. AIManufacturingandServices_Report_02.pdf , pp5-12AI and the Manufacturing and Services Industry in India, Report by GeethanjaliJujjavarapu, Elonnai Hickok, Amber Sinha, https://cis-india.org/internetgovernance/files/

AIManufacturingandServices_Report_02.pdf , pp15-16

13. Behera LK (2013), "Indian Defence Industry: Issues Of Self-Reliance”, IDSA Monograph Series No 21, Pp5-13, 27-31, July 2013, https://idsa.in/system/files/monograph21.pdf

14. Prahlada (2016)-“Self-Reliance Through Smart Acquisition", pp262, https://idsa.in/system/files/book/book_DefAcq.pdf

15. Prasad A (2016), "Indian Ordnance Factories: An Agenda for Change", https://idsa.in/system/files/book /book_DefAcq.pdf, pp270-287

16. Behera (2016) , Indian Defence industry: An Agenda for Making in India. https://idsa.in/book/indian-defenceindustry_lkbehra

17. Ghosh R, 2016, "Indigenisation: Key to Self-Sufficiency and Strategic Capability", Pentagon Press.https://idsa.in/system/files/book/book-indiadefence_0.pdf

18. Sniderman B, Mahto Monika and Cotteleer MJ (2017), Industry 4.0 and manufacturing ecosystems: Exploring the world of connected Enterprises, Deloitte university press,https://www2.deloitte.com/content/dam/insights/us/ articles/manufacturing-ecosystems-exploring-worldconnectedenterprises/DUP_2898_Industry4.0ManufacturingEcosys tems.pdf

19. Poonian Naveen (2019), "Gearing up for the Defence Industries Digital transformation" https://defense systems.com/opinion... Accessed on 15 May 2019.

\section{AUTHORS PROFILE}

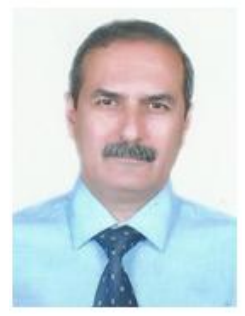

Pawan Anand, serving as an Additional Director General in GoI with over 35 years of experience, is a Mechanical Engineer, with a Masters in Management Sciences from Osmania University, and M Phil in Strategic Studies, from Madras University. He has publications to his credit in subjects varying from infrastructure development on India's northern borders to IndoUS defence trade. He is currently researching indigenisation of India's defence industrial base, under the aegis of Symbiosis International (Deemed University). He is a member of the Institution of Engineers (India) and the United Services Institute, Delhi. An overall topper from his university days, he has been a keen badminton and squash player at the national level.

Emailpawan.anandmg@gmail.com.

Dr. Asha Nagendra

Msc, Phd, Post Doctoral Senior Research Fellow

An alumnus of SIBM, Pune, Dr Asha Nagendra completed her PhD in Organizational Management from Pune University. She was awarded a Senior Research Fellowship for Post Doctoral Research in Human Resource Management by Indian Council of Social Science Research 
(ICSSR), New Delhi to pursue research on "Strategic Human Resource Management - Human Resource Climate and Performance Appraisal System of Personnel in the Automobile Industry (Tata Motors and Bajaj Auto) in Pune" from Dec 2002 to May 2005. She has been teaching in Symbiosis International University for the last fifteen years. In 2010, she was appointed Director, Symbiosis Centre for Management Studies (UG), at NOIDA, UP, the off campus institute of Symbiosis International University, Pune and has returned after successfully setting up the institute at NOIDA. With her strong research background she is a $\mathrm{PhD}$ guide in 4 Universities including Symbiosis International University, Pune. 16 students have received $\mathrm{PhD}$ under her guidance. 08 pursuing $\mathrm{PhD}$ presently in the Faculty of Management. She has attended many national seminars and conferences and has a number of research papers, both National and International to her credit. With a rich experience of forty years of teaching and research, she has conducted Faculty Development Programs on "Writing a Research Paper" at various institutes. Currently, she is the Professor at the Symbiosis Institute of Management Studies, Khadki, Pune.

Contact details:

email id

Telephone

asha.nagendra@ sims.edu

Mobile No

020-26803684

$+91-8055399996$ 